J. Akademika Kim. 4(4): 168-174, November 2015

ISSN 2302-6030 (p), 2477-5185 (e)

\title{
ANALISIS KADAR KARBOHIDRAT, LEMAK DAN PROTEIN DARI TEPUNG BIJI MANGGA (Mangifera indica L) JENIS GADUNG
}

\section{Content Analysis of Carbohydrate, Fat and Protein of Flour Seeds Mango (Mangifera indica L) Type of Gadung}

\author{
* Umi Qalsum, Anang W. M. Diah, dan Supriadi \\ Pendidikan Kimia/FKIP - Universitas Tadulako, Palu - Indonesia 94118 \\ Received 03 September 2015, Revised 05 October 2015, Accepted 04 November 2015
}

\begin{abstract}
Mango (Mangifera indica L) seeds never to used, so they need efforts to be as food ingredients such as flour. Gadung mango seed was one type of mango seeds used as flour. This study aims to determine the nutrient content i.e. carbohydrates, fats, and proteins of Gadung mango seed flour produced through sulfurization and without sulfurization. Sodiumbisulfite $\left(\mathrm{NaHSO}_{3}\right)$ with a concentration of $730 \mathrm{ppm}$ was used for mango seed soak for 4 hours at sulfurization stage. The results showed that the Gadung mango seed flour through sulfurization had levels of $13.89 \%$ carbohydrate, $12.94 \%$ fat and $8.48 \%$ protein, while the mango seed flour without sulfurization had levels of $20 \%$ carbohydrate, $14.83 \%$ fat, and $4.84 \%$ protein. The technique of sulfurization on making mango seed flour can reduce levels of carbohydrates and fats as well as maintaining the protein content.
\end{abstract}

Keywords: Mango seed, flour, sulfurization, carbohydrate, Fat, Protein.

\section{Pendahuluan}

Negara Indonesia merupakan negara megadiversity, termasuk dalam kekayaan flora (tumbuhan) yang menempatkan Indonesia dalam urutan kelima di dunia. Sehingga Indonesia merupakan salah satu negara penghasil komoditas holtikultura yang cukup penting (Alamendah, 2012). Komoditas holtikultura di Indonesia merupakan salah satu komoditas hasil pertanian yang memiliki nilai ekonomis tinggi. Salah satu pemanfaatannya yaitu dijadikan sebagai bahan pangan untuk memenuhi sumber gizi yang dibutuhkan manusia. Menurut Peraturan Pemerintah RI nomor 28 tahun 2004, pangan adalah segala sesuatu yang berasal dari sumber hayati dan air, baik yang diolah maupun yang tidak diolah, yang diperuntukkan sebagai makanan atau minuman bagi konsumsi manusia. Pengembangan produk pangan melalui aneka bentuk olahan merupakan salah satu cara untuk menambah nilai ekonomi produk pangan (Lumba, 2012).

Salah satu tanaman yang menghasilkan nilai ekonomis tinggi dalam produk pangan

\section{${ }^{*}$ Correspondence:}

Umi Qalsum

Program Studi Pendidikan Kimia, Fakultas Keguruan dan

Ilmu Pendidikan, Universitas Tadulako

email: umiqalsum121@gmail.com

Published by Universitas Tadulako 2015

adalah buah mangga. Buah ini memiliki rasa yang manis dan berbau harum serta kaya akan vitamin $\mathrm{C}$, vitamin $\mathrm{E}$, serat dan zat-zat lainnya yang dibutuhkan oleh tubuh manusia (Ashoush \& Gadallah, 2011). Umur simpan buah mangga relatif pendek karena buah ini termasuk bahan pangan yang mudah rusak. Bagian buah mangga yang banyak dimanfaatkan yaitu dagingnya (Widya, 2003). Biasanya dibuat sirup, jus mangga, selai, saus, es buah dan acar (Nzikou, 2010). Susunan buah mangga dapat dibagi dalam tiga bagian yaitu kulit, daging dan biji. Komposisi buah mangga terdiri dari kulit buah dengan bobot berkisar antara 11-18\%, biji 14-22\% serta daging buah yang berkisar antara $60-75 \%$ dari berat buah (Kittiphoom, 2012). Varietas mangga banyak sekali, yang membedakannya adalah besar buahnya, rasanya, aromanya, demikian juga bentuk pohon dan daunnya. Di Indonesia, jenis-jenis mangga yang sering dijumpai, yaitu arumanis, gadung, golek, indramayu, dan manalagi. Adapun ciri khas dari buah mangga gadung di Indonesia, yaitu buahnya yang besar, berbentuk lonjong, daging berwarna orange terang, bijinya berukuran besar, tapi rasanya kurang manis dibanding mangga jenis lainnya (Dewi, 2013).

Biji mangga yang terbuang dan menjadi 
limbah ternyata secara umum memiliki kandungan nutrisi yang cukup tinggi, yaitu meliputi karbohidrat 73,09\%, protein 7,39\% dan lemak 6,38\% (Widya, 2003). Biji buah mangga dapat dimanfaatkan menjadi tepung ataupun makanan tradisional. Caranya yaitu biji diambil bagian tengahnya, terlebih dahulu membuang selaput tipis yang menyelimutinya. Selanjutnya biji mangga dicuci bersih dan dikeringkan. Setelah kering ditumbuk hingga menjadi tepung dan dijemur kembali. Usai begitu tepung bisa dikonsumsi menjadi makanan sejenis bubur, jenang atau gorengan (Arianto, 2012). Tepung adalah bahan baku utama pembuatan berbagai jenis makanan (kue). Disamping sebagai sumber pati (gizi), tepung juga sebagai pembentuk struktur. Sifat fisik tepung yang harus diperhatikan adalah harus berwarna putih, tidak menggumpal dan tidak lengket (Putri, 2010). Tepung biji-bijian dapat dihasilkan dari beberapa tahapan proses yaitu perendaman (sulfurisasi), blanching, pengeringan dan penggilingan. Proses perendaman dilakukan dengan cara bahan direndam ke dalam larutan natrium bisulfit dengan konsentrasi $730 \mathrm{ppm}$ pada temperatur konstan $\left(28^{\circ} \mathrm{C}-30^{\circ} \mathrm{C}\right)$ selama tidak lebih dari 72 jam. Hal ini bertujuan untuk mempertahankan warna dari bahan dan mencegah terjadinya reaksi pencoklatan non enzimatis maupun enzimatis, serta untuk menghambat pertumbuhan mikroba (Rizal \& Sumarlan, 2013).

\section{Metode}

Penelitian dilakukan di Laboratorium Agroteknologi Fakultas Pertanian Universitas Tadulako, Palu. Peralatan yang digunakan : tabung dekstruksi, alat dekstruksi, alat distilasi dan titrasi, alat ekstraksi Soxhlet, labu Soxhlet, Cimarec Stirring and Hot Plates, gelas kimia, timbangan analitik, pipet tetes, pipet ukur, pipet mikro, karet penghisap, pompa vakum, gelas ukur, labu ukur, Magnetik stirer, corong gelas, pengaduk, ayakan 80 mesh, spektrofotometer UV-Vis, gegep (penjepit), oven dan desikator. Bahan-bahan yang digunakan: Biji mangga gadung, air, larutan natrium bisulfit $730 \mathrm{ppm}$, n-Heksana, larutan $\mathrm{HCl} 0,085 \mathrm{~N}$, Indikator metil merah, campuran $\mathrm{K}_{2} \mathrm{SO}_{4}$ dan $\mathrm{HgO}$, larutan $\mathrm{NaOH} 45 \%$, larutan $\mathrm{H}_{3} \mathrm{BO}_{3} 2 \%$, aquades, larutan $\mathrm{H}_{2} \mathrm{SO}_{4}$ pekat, larutan fenol $5 \%$, padatan glukosa, larutan $\mathrm{HClO}_{4} 52 \%$, aluminium foil dan kertas saring.

Preparasi sampel yang dilakukan, yaitu memisahkan kulit buah, daging dan kulit keras biji mangga gadung sehingga diperoleh biji bagian dalamnya. Kemudian mencuci biji tersebut dengan air secara berulang-ulang sampai air cuciannya agak jernih. Setelah itu mengirisnya tipis-tipis dengan ketebalan 0,3 $0,5 \mathrm{~cm}$. Kemudian biji tersebut dibuat tepung dengan tanpa tahap sulfurisasi dan memakai sulfurisasi.

Pembuatan tepung biji mangga gadung tanpa tahap sulfurisasi: Pembuatan tepung dengan cara ini dilakukan melalui proses blanching terhadap biji mangga yang telah disiapkan tahap, yaitu memanaskan biji mangga di dalam air dengan suhu $80^{\circ} \mathrm{C}-90^{\circ} \mathrm{C}$ selama 5 menit. Selanjutnya meniriskannya dengan kain saringan. Biji mangga tersebut dikeringkan menggunakan oven pada suhu $60^{\circ} \mathrm{C}$ selama 13 jam. Setelah itu proses penggilingan dengan menghaluskan biji mangga menggunakan blender dan mengayaknya dengan ayakan 80 mesh (Widya, 2003)

Pembuatan tepung biji mangga gadung memakai tahap sulfurisasi: Pembuatan tepung dengan cara ini dilakukan melalui proses sulfurisasi, yaitu merendam biji mangga di dalam larutan natrium bisulfit $(730 \mathrm{ppm})$ pada suhu konstan $\left(28^{\circ} \mathrm{C}-30^{\circ} \mathrm{C}\right)$ selama 4 jam dan meniriskannya menggunakan saringan kain. Setelah itu melakukan proses blanching, yaitu memanaskan biji mangga di dalam air dengan suhu $80^{\circ} \mathrm{C}-90^{\circ} \mathrm{C}$ selama 5 menit. Selanjutnya meniriskannya dengan kain saringan. Biji mangga tersebut dikeringkan menggunakan oven pada suhu $60^{\circ} \mathrm{C}$ selama $13 \mathrm{jam}$. Setelah itu proses penggilingan dengan menghaluskan biji mangga menggunakan blender dan mengayaknya dengan ayakan 80 mesh (Widya, 2003)

\section{Analisis Kadar Karbohidrat}

Preparasi sampel untuk analisis karbohidrat

Tahap-tahap yang dilakukan untuk analisis sampel mengikuti prosedur yang sudah dilakukan oleh (Apriantono, 1988), yaitu: Menimbang tepung biji mangga gadung tanpa sulfurisasi sebanyak 1 gram dan menambahkan $10 \mathrm{~mL}$ aquades sambil mengaduknya. Menambahkan $13 \mathrm{~mL}$ asam perklorat $\left(\mathrm{HClO}_{4}\right) \quad 52 \%$ dan mengaduknya selama 20 menit menggunakan magnetik stirer dengan menutup gelas kimia dengan kertas alumunium. Menambahkan aquades sebanyak $100 \mathrm{~mL}$ dan menyaringnya ke dalam labu takar $250 \mathrm{~mL}$. Menambahkan aquades sampai batas tera labu ukur $250 \mathrm{~mL}$. Mengulangi perlakuan tersebut untuk tepung biji mangga gadung secara sulfurisasi. 


\section{Pengukuran kadar karbohidrat}

Prosedur untuk analisis karbohidrat merujuk seperti yang telah dilakukan oleh (Apriantono, 1988), yaitu: Membuat larutan glukosa standar dengan konsentrasi $(0,20,40$ dan 60, 80 dan $90 \mathrm{ppm}$ ). Mengambil $1 \mathrm{ml}$ dari masingmasing larutan. Menambahkan $1 \mathrm{ml}$ larutan fenol 5\% dan mengocoknya. Menambahkan dengan cepat $5 \mathrm{ml}$ larutan asam sulfat pekat dan merendamnya di dalam air, kemudian mendiamkan selama 10 menit. Mengukur absorbannya pada panjang gelombang $490 \mathrm{~nm}$. Membuat kurva standar. Mengulangi perlakuan yang sama dengan mengganti larutan standar glukosa menjadi sampel. Melakukan perlakuan sebanyak 2 kali. Mengulangi perlakuan di atas untuk tepung biji mangga dengan sulfurisasi.

Kadar karbohidrat dinyatakan dalam persen glukosa $(\%)=(\mathrm{G}) / \mathrm{W} \times 100$ dimana $\mathrm{G}=$ Konsentrasi glukosa $(\mathrm{g})$ dan $\mathrm{W}=$ Berat sampel (g) (Desyanti, 2013).

\section{Analisis Kadar Lemak}

Kadarlemak dianalisis dengan menggunakan metode Ekstraksi Soxhlet (Apriantono, 1988), yaitu: Mengeringkan labu dalam oven yang ukurannya sesuai alat ekstraksi soxhlet. Setelah itu mendinginkan di dalam desikator dan menimbangnya. Menimbang sebanyak 2 gram tepung biji mangga gadung tanpa sulfurisasi, kemudian membungkus dengan kapas dan kertas saring. Memasukkan sampel ke dalam alat extraksi soxhlet, memasang alat kondensor di atasnya dan labu di bawah alat soxhlet. Mengisi secukupnya pelarut $n$-heksana ke dalam labu. Melakukan proses refluks sampai pelarut turun kembali ke labu dan hasilnya berwarna jernih. Memanaskan labu sampai pelarutnya mendidih dan menguap naik ke sampel yang dibungkus kertas saring sampai turun ke labu hingga pelarut dalam labu berkurang. Memanaskan labu yang berisi lemak hasil ekstraksi di dalam oven pada suhu $105^{\circ} \mathrm{C}$, lalu mendinginkan dalam desikator kemudian menimbang sampai beratnya tetap. Melakukan perlakuan sebanyak 2 kali dan mengulangi perlakuan tersebut untuk tepung biji mangga gadung dengan sulfurisasi. Menghitung kadar lemak dengan rumus sebagai berikut :

Kadar lemak $(\%)=\frac{\text { Berat labu akhir }- \text { Berat labu awal } x \text { 100\% }}{\text { Berat sampel kering }}$

\section{Analisis Kadar Protein}

Kadar protein di analisis dengan menggunakan metode mikro-Kjeldahl
(Apriantono, 1988), yaitu: Menimbang tepung biji mangga gadung tanpa sulfurisasi sebanyak 0,5 gram dan memasukkannya ke dalam tabung dekstruksi. Menambahkan 1 gram campuran $\left(\mathrm{K}_{2} \mathrm{SO}_{4}\right.$ dan $\left.\mathrm{HgO}\right)$ dan $10 \mathrm{~mL}$ larutan $\mathrm{H}_{2} \mathrm{SO}_{4}$ pekat. Mendestruksi (memanaskan) semua bahan dalam tabung dekstruksi sampai mendidih hingga larut dan cairan menjadi jernih. Setelah itu menghentikan pemanasan dan membiarkannya sampai dingin. Melakukan proses distilasi, kemudian proses titrasi terhadap distilat. Menghentikan proses titrasi pada saat distilat berubah warna menjadi merah. Membuat larutan blangko dengan menggantikan sampel dengan aquades. Melakukan destruksi, destilat dan titrasi seperti pada sampel. Melakukan perlakuan sebanyak dua kali dan mengulangi perlakuan untuk tepung biji mangga gadung dengan sulfurisasi. Persentase protein dalam tepung biji mangga gadung tanpa sulfurisasi dihitung dengan menggunakan rumus sebagai berikut :

$$
\text { Persentase kadar } \mathrm{N}=\frac{(\mathrm{ts}-\mathrm{tb}) \times \mathrm{N} \mathrm{HCl} \times 14,008 \times 100 \%}{\mathrm{mg} \mathrm{Sampel}}
$$

$\%$ Kadar Protein $=\% \mathrm{~N}$ x 6,25 dimana ts: Volume titrasi sampel dan tb: Volume titrasi blangko

\section{Hasil dan Pembahasan \\ Kadar Karbohidrat}

Karbohidrat adalah hasil alam yang memiliki banyak fungsi penting dalam tanaman maupun hewan. Melalui fotosintesa, tanaman merubah karbon dioksida menjadi karbohidrat, yaitu dalam bentuk selulosa, pati, dan gulagula. Karbohidrat dalam tepung terdiri dari karbohidrat dalam bentuk gula sederhana, pentosa, dextrin, selulosa, dan pati (Setiyono, 2011). Sebagian besar karbohidrat, terutama golongan monosakarida dan disakarida seperti glukosa, fruktosa, galaktosa, dan laktosa mempunyai sifat mereduksi. Sifat mereduksi dari karbohidrat disebabkan oleh adanya gugus aldehida atau gugus keton bebas dan gugus $\mathrm{OH}$ bebas (Daud, 2012).

Kadar karbohidrat diukur dengan menggunakan metode fenol sulfat. Prinsip dari metode ini adalah gula sederhana dan oligosakarida dapat bereaksi dengan fenol dalam asam sulfat pekat menghasilkan warna jingga kekuningan yang stabil. Dimana oligosakarida 
dihidrolisis menjadi monosakarida oleh asam sulfat pekat dan menghidrasinya sehingga membentuk senyawa furfural yang bereaksi dengan fenol menghasilkan warna jingga kekuningan. Penerapan metode fenol-sulfat banyak digunakan untuk menentukan karbohidrat dalam sampel secara langsung yang dinyatakan sebagai persen glukosa (Amalia \& Sartika, 2014).

Penelitian ini mengukur kadar karbohidrat pada tepung biji mangga gadung yang tanpa tahap sulfurisasi dan memakai tahap sulfurisasi. Sebelum menganalisis sampel, terlebih dahulu melakukan ekstraksi sampel dengan menggunakan asam perklorat $52 \%$ yang dapat menghidrolisis pati dan melarutkan gula-gula yang ada pada sampel (Apriantono, 1988). Setelah diperoleh ekstrak sampel, dilakukan pembuatan larutan standar glukosa dengan menambahkan larutan fenol $5 \%$ dan asam sulfat pekat. Warna larutan standar glukosa berubah dari tak berwarna menjadi warna jingga kekuningan. Hal ini terjadi karena asam sulfat pekat ketika direaksikan dengan fenol dan glukosa menghasilkan panas yang menyebabkan glukosa terhidrasi menjadi senyawa hidroksimetil furfural. Senyawa ini ketika bereaksi dengan fenol akan menghasilkan warna jingga kekuningan (Amalia \& Sartika, 2014)
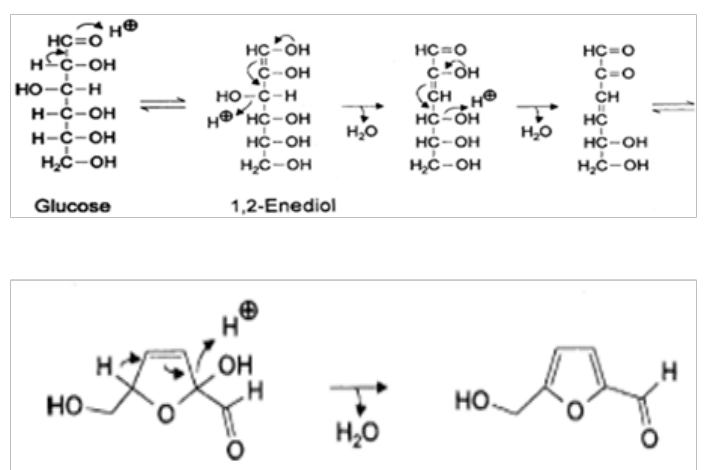

Gambar 1. Reaksi glukosa dengan asam sulfat pekat (Lewkowski, 2001)

Untuk sampel dilakukan hal yang sama seperti pada larutan standar yang menghasilkan warnajingga kekuningan. Kemudian melakukan pengukuran absorban larutan glukosa standar pada konsentrasi $0,20,40,60,80$ dan 90 ppm pada panjang gelombang $490 \mathrm{~nm}$. Hal ini bertujuan untuk memperoleh konsentrasi sampel dengan menggunakan persamaan regresi yang diperoleh dari pengukuran absorbansi larutan standar, yaitu adalah $Y=0,016 x+0,047$. Tahap berikutnya adalah pengukuran absorban sampel yang dilakukan sebanyak dua kali perlakuan. Dengan menggunakan persamaan regresi diperoleh konsentrasi sampel tepung biji mangga tanpa tahap sulfurisasi dan memakai tahap sulfurisasi secara berturut-turut adalah 80,00 ppm dan 55,56 ppm. Kadar karbohidrat dari masing-masing sampel diperoleh dalam bentuk persen glukosa (\%) dan dapat dilihat pada Tabel 1.

Tabel 1. Kadar Lemak Tepung Biji Mangga Gadung

\begin{tabular}{|c|l|c|}
\hline No. & \multicolumn{1}{|c}{ Sampel } & Kadar Lemak (\%) \\
\hline 1. & Tepung tanpa sulfurisasi & 14,92 \\
\hline 2. & $\begin{array}{l}\text { Tepung memakai } \\
\text { sulfurisasi }\end{array}$ & 12,94 \\
\hline
\end{tabular}

Berdasarkan data Tabel 1 meperlihatkan bahwa kadar lemak pada tepung biji mangga tanpa sulfurisasi lebih tinggi (14,83\%) dibandingkan dengan tepung yang memakai sulfurisasi $(12,94 \%)$. Hal ini di duga karena perendaman dengan natrium bisulfit yang dilakukan selama 4 jam. Waktu perendaman yang cukup lama membuat jaringan sel makin rusak dan berlubang-lubang sehingga lemak dalam sel terdifusi keluar sel. Selain itu, proses perendaman menyebabkan pemecahan lemak menjadi asam-asam lemak sehingga makin banyak asam lemak yang volatil saat pengeringan (Prabasini \& Ishartani, 2013).

\section{Kadar Protein}

Protein merupakan sumber asam amino yang mengandung unsur-unsur $\mathrm{C}, \mathrm{H}, \mathrm{O}$ dan $\mathrm{N}$ yang tidak dimiliki oleh lemak dan karbohidrat. Protein merupakan komponen yang banyak terdapat pada sel tanaman dan hewan. Kandungan protein dalam bahan pangan bervariasi baik dalam jumlah maupun jenisnya. Protein merupakan sumber gizi utama, yaitu sebagai sumber amino. Disamping berperan sebagai sumber gizi, protein dari sumber yang berbeda memiliki kekhasan sifat fungsional yang berpengaruh pada karakteristik produk pangan (Paramita, 2012). Karena adanya kandungan unsur $\mathrm{N}$ maka biasanya dalam penentuan jumlah protein dapat dilakukan dengan cara menentukan jumlah nitrogen $(\mathrm{N})$ yang ada 
dalam bahan pangan. Penentuan jumlah $\mathrm{N}$ total dilakukan untuk mewakili jumlah protein yang ada dan metode pengukuran kadar protein ini adalah metode Kjeldahl dimana pengukuran didasarkan atas pengukuran kandungan nitrogen total di dalam bahan pangan (Novika, 2013). Metode Kjeldahl terbagi atas tiga tahap, yaitu tahap dekstruksi, distilasi dan titrasi. Tahap dekstruksi terjadi penguraian sampel menjadi unsur-unsurnya yaitu $\mathrm{H}, \mathrm{O}$, $\mathrm{N}$, dan $\mathrm{C}$ oleh asam sulfat pekat yang bersifat oksidator kuat. Elemen karbon (C), hidrogen (H) akan teroksidasi menjadi $\mathrm{CO}_{2}, \mathrm{CO}$ dan $\mathrm{H}_{2} \mathrm{O}$, sedangkan nitrogen $(\mathrm{N})$ akan berubah menjadi $\left(\mathrm{NH}_{4}\right)_{2} \mathrm{SO}_{4}$ (Sadli, 2014). Proses dekstruksi dibantu dengan adanya katalisator yang berfungsi untuk mempercepat kenaikan suhu asam sulfat yang berkisar pada suhu 370 oC- $410^{\circ} \mathrm{C}$, sehingga dekstruksi berjalan dengan cepat. Katalisator yang digunakan adalah campuran dari padatan $\mathrm{K}_{2} \mathrm{SO}_{4}$ dan $\mathrm{HgO}$, dimana 1 g $\mathrm{K}_{2} \mathrm{SO}_{4}$ dapat menanikkan titik didih $3^{\circ} \mathrm{C}$. Proses ini dihentikan ketika larutan sampel menjadi jernih.

Tahap distilasi bertujuan untuk memisahkan zat yang diinginkan, yaitu memecah amonium sulfat $\left(\mathrm{NH}_{4}\right)_{2} \mathrm{SO}_{4}$ menjadiamonia $\left(\mathrm{NH}_{3}\right)$ dengan menambahkan $\mathrm{NaOH}$. Fungsi penambahan $\mathrm{NaOH}$ adalah untuk memberikan suasana basa, karena reaksi tidak dapat berlangsung asam. Uap amonia yang telah diperoleh dari pemecahan amonium sulfat ditangkap oleh larutan asam borat $\left(\mathrm{H}_{3} \mathrm{BO}_{3}\right)$ yang sebelumnya telah dicampur dengan indikator metil merah. Proses distilasi dihentikan ketika hasil destilat berwarna biru.

Tahap titrasi bertujuan untuk mengetahui berapa banyak asam borat bereaksi dengan amonia. Dimana hasil distilat ditrasi dengan $\mathrm{HCl}$. Larutan $\mathrm{HCl}$ akan mentitrasi amoniumborat menjadi amonium klorida sehingga pada akhir titrasi terjadi kelebihan $\mathrm{HCl}$. Akhir titrasi ditandai dengan perubahan larutan dari biru/hijau menjadi merah. Selain sampel, ada juga blanko yang melalui tiga tahap tersebut. Blanko berfungsi sebagai faktor koreksi terhadap senyawa $\mathrm{N}$ yang berasal dari pereaksi yang digunakan. Hasil titrasi yang diperoleh dapat mencari kadar nitrogen dan dikonversi ke protein dengan mengalikan kadar nitrogen dengan faktor konversi yaitu 6,25 yang diperoleh dari 100/16 (Bintang, 2010). Unsur nitrogen adalah unsur utama protein, karna terdapat di dalam semua protein yang memiliki proporsi $16 \%$ dari total protein. Kadar protein untuk masing-masing sampel dapat dilihat pada Tabel 2.

Tabel 2. Kadar Tepung Biji Mangga Gadung

\begin{tabular}{|l|l|c|}
\hline \multirow{2}{*}{ No } & \multicolumn{1}{|c}{ Sampel } & Kadar Protein (\%) \\
\hline 1 & Tepung tanpa sulfurisasi & 4,84 \\
\hline 2 & Tepung memakai sulfurisasi & 8,48 \\
\hline
\end{tabular}

Tabel 2 memperlihatkan bahwa kadar protein pada tepung biji mangga tanpa sulfurisasi lebih rendah $(4,84 \%)$ dibandingkan dengan tepung yang memakai sulfurisasi $(8,48 \%)$. Hal ini disebabkan karena terjadi reaksi pencoklatan non enzimatis atau reaksi Maillard, yaitu reaksi yang terjadi antara gula pereduksi dengan asam amino dari protein sehingga menghasilkan senyawa melanoidin yang berwarna coklat. Tahap awal dari reaksi Maillard adalah kondensasi antara a-amino dari asam amino atau protein dengan gugus karbonil dari gula pereduksi. Tahap ini disebut reaksi karbonilamino dan produk awal yang terbentuk akan kehilangan air, membentuk basa Schiff diikuti dengan siklisasi menghasilkan glikosilamin yang tersubstitusi N. Senyawa ini sangat labil sehingga mengalami isomerisasi menjadi asam fruktosamino (1-amino-1deoksi-2-ketosa). Reaksi ini disebut Amadori rearrangement. Selanjutnya, dehidrasi senyawa Amadori yang diubah menjadi turunan fulfuraldehid, misalnya hidroksimetil dan furaldehid. Proses dehidrasi selanjtnya menghasilkan hasil antara reduktor-reduktor seperti metil glioaksal, asetol dan disetil. Aldehid-aldehid yang aktif dari pengubahan senyawa Amadori tersebut akan terpolimerasi dengan gugus amino membentuk senyawa melanoidin yang berwarna coklat (Chandra, 2010). Reaksi Maillard dapat dilihat pada Gambar 3.

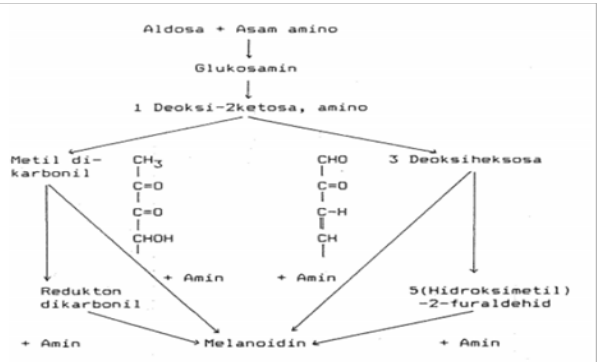

Gambar 2. Reaksi Maillard (Chandra, 2010) 
Tepung biji mangga yang memakai tahap sulfurisasi lebih tinggi dibandingkan dengan tepungbiji mangga tanpasulfurisasidikarenakan proses sulfurisasi yang menggunakan senyawa sulfit dapat menghambat reaksi Maillard. Natrium bisulfit dapat bereaksi dengan gugus gula pereduksi, sehingga sulfurisasi dapat menekan penurunan kadar protein dalam tepung biji mangga tersebut (Widiyowati, 2007).

\section{Kesimpulan}

Kadar karbohidrat, Lemak dan Protein yang diperoleh dari tepung biji mangga tanpa melalui tahap sulfurisasi: Karbohidrat 20,00\%, Lemak 14,83\%, dan Protein 4,84\%. Komposisi Karbohidrat, Lemak dan Protein yang diperoleh dari tepung biji mangga melalui tahap sulfurisasi: Karbohidrat: 13,89\%, Lemak: $12,94 \%$ dan Protein 8,48\%. Kandungan nutrisi tepung biji mangga memakai tahap sulfurisasi mengalami penurunan dibandingkan dengan tepung tanpa tahap sulfurisasi, khususnya pada kadar karbohidrat dan lemak tetapi dapat menekan penurunan kadar protein.

\section{Ucapan Terima Kasih}

Ucapan terima kasih penulis berikan kepada laboran Laboratorium Agroteknologi FAPERTA Universitas Tadulako yang banyak membantu penulis dalam menyelesaikan penelitian ini.

\section{Referensi}

Alamendah. (2012). Flora. Diunduh kembali dari http://alamendah.org/frolar/html

Amalia, A., \& Sartika, A. (2014). Review karbohidrat kelompok IV far. Diunduh kembali dari https://www.scribd.com/ doc/241025804/Review-KarbohidratKelompok-VI-Far-A/html.

Apriantono, A. (1988). Analisis pangan. Bandung: ITB.

Arianto. (2012). Ini dia manfaat biji buah mangga. Diunduh kembali dari http://www. timlo.net/baca/37717/ini-dia-manfaat-bijibuah-mangga/html.
Ashoush, I. S., \& Gadallah, M. G. E. (2011). Utilization of mango peels and seed kernels powders as sourcesof phytochemicals in biscuit. Journal of Dairy \& Food Sciences 6(1), 35-42.

Bintang, M. (2010). Biokimia teknik penelitian. Jakarta: Erlangga.

Chandra, A. (2010). Pengaruh $p H$ dan jenis pelarut pada percobaan dan karakterisasi pati dari biji alpukat. Diunduh kembali dari http://journal.unpar.ac.id/index.php/ rekayasa/article/download/253/238.

Daud, M. (2012). Biokonversi bahan berlignoselulosa menjadi bioetanol menggunakan aperligus niger dan saccharomyces cerevisiae. Jurnal Perennial, $8(2), 43-51$.

Desyanti, M. (2013). Analisa kualitatif dan kuantitatif karbohidrat. Diunduh kembali dari https://www.scribd.com/ doc/147498064/Analisa-Kualitatif-DanKuantitatif-Karbohidrat.

Dewi. (2013). Super mangga. Diunduh kembali dari https://medium.com/p/f733afc982d8.

Hidayat, R. (2010). Mempelajari pembuatan tepung pisang raja bulu kaya b-karoten dan karakterisasi mutunya. Institut Pertanian Bogor, Bogor. Diunduh kembali dari http://repository.ipb.ac.id/ handle/123456789/59925

Kittiphoom, S. (2012). Utilization Of Mango Seed. Internatoinal Food Research Journal, 19(4), 1325-1335.

Lewkowski, J. (2001). Syhthesis, chemistry and application of 5-hydroxymetilfulfural and its derivatives. Journal ARKIVOC, 1(1), 17 54. 
Lumba, R. (2012). Kajian pembuatan beras analog berbasis tepung umbi daluga (Crytosperma merkusii (Hassk) Schott). Jurnal Universitas Samratulangi, 5(1), 1-13.

Novika, C. (2013). Kajian penggunaan tepung millet kuning sebagai subtitusi tepung terigu pada karakteristik sensoris, fisikokimia dan aktivitas antioksidan mi instan ubi jalar ungu. Jurnal Teknosains, 2(1), 1-8.

Nzikou, J. M. (2010). Extraction and characteristics of seed kernel oil from manggo (Mangifera indica). Research Journal of Evironmental and Earth Sciences, 2(1), 31-35.

Paramita, O. (2012). Kajian proses pembuatan tepung buah mangga (Mangifera indica L) varietas arumanis dengan suhu perendaman yang berbeda. Jurnal Bahan Terbarukan, 1(1), 1-10.

Prabasini, H., \& Ishartani, D. (2013). Kajian sifat kimia dan fisik tepung labu kuning (Cucurbita Moschata) dengan perlakuan blanching dan perendaman dalam natrium metabisulfit $\left(\mathrm{Na}_{2} \mathrm{~S}_{2} \mathrm{O}_{5}\right)$. Jurnal Teknosains Pangan, 2(2), 1-10.

Putri, F. M. (2010). Kandungan gizi dan sifat fisik tepung ampas kelapa sebagai bahan pangan sumber serat. Jurnal TEKNUBUGA,
2(2), 1-12.

Rizal, S., \& Sumarlan, S. H. (2013). Pengaruh konsentrasi natrium bisulfit dan suhu pengeringan terhadap sifat fisikkimia tepung biji nangka (Artocarpus heterophyllus). Jurnal Bioproses Komoditas Tropis, 1(2), 1-10.

Sadli. (2014). Analisis kandungan karbohidrat, lemak dan protein dari biji durian (Durio zibethinus Murr) dengan variasi waktu pengukusan. Palu: Universitas Tadulako.

Setiyono, L. (2011). Pemanfaatan biji kurma (Phoenix dactylifera L.) sebagai tepung dan analisis perubahan mutunya selama penyimpanan. Bogor: Institut Teknologi.

Widiyowati, I. I. (2007). Pengaruh lama perendaman dan kadar natrium metabisulfit dalam larutan perendaman pada potongan ubi jalar kuning (Ipomea batatas (L) Lamb) terhadap kualitas tepung yang dihasilkan. Jurnal Teknologi Pertanian, 2(2), 55-58.

Widya, D. (2003). Proses produksi dan karakteristik tepung biji mangga jenis arumanis (Mangifera indica L.). Institut Teknologi Bogor, Bogor. Diunduh kembali dari http://repository.ipb.ac.id/ handle/123456789/19436 